\title{
A LITERATURA NO CINEMA: A QUESTÃO DO ANALFABETISMO EM VIDAS SECAS
}

Maurina Lima Silva

Mestranda em Letras pela Universidade Federal de São Paulo (UNIFESP)

maurina_cba@hotmail.com

\section{RESUMO}

O presente texto tem como objetivo comparar o romance Vidas secas (1938), de Graciliano Ramos, com sua adaptação (1963) para o cinema, do diretor Nelson Pereira dos Santos. O foco é a analfabetismo dos personagens. Como o analfabetismo e suas consequências sociais aparecem no romance? Como o cineasta abordou esse assunto? Sem a pretensão de esgotar as duas obras, tendo em vista o enredo literário e o adaptado, comparam-se trechos do romance a cenas do filme a fim de refletir sobre a representação artística do analfabeto.

Palavras-chave: Vidas Secas, analfabetismo, literatura e cinema.

\section{ABSTRACT}

The present text aims to compare the novel Vidas secas (1938), by Graciliano Ramos, with his adaptation (1963) to the cinema directed by Nelson Pereira dos Santos. The focus is the illiteracy of the characters. How does illiteracy and its social consequences emerge in the novel? How did the filmmaker manage this? Considering the literary and adapted plot, without pretending to exhaust the two works, we compare parts of the novel to scenes from the film in order to inquire about the artistic representation of the illiterate.

Keywords: Vidas secas, Illiteracy, literature and cinema. 
Este texto tem como propósito analisar o romance Vidas secas (1938), de Graciliano Ramos, e o filme com o mesmo nome, do diretor Nelson Pereira dos Santos (1963). Sinaliza-se, entretanto, que o estudo focará a questão do analfabetismo dos personagens, nesse sentido as perguntas são: como o analfabetismo e as consequências desta condição surgem nesse romance? E quais as escolhas feitas por Nelson Pereira Santos ao tratar desse assunto no filme?

Vidas secas é composto por 13 capítulos que não possuem uma linearidade temporal. Nele são narradas as agruras de uma família sertaneja (Fabiano, sinha Vitória, e os filhos mais novo e mais velho) na caminhada pela aridez impiedosa da caatinga, fugindo das piores condições de vida. O livro traz à tona uma realidade brasileira, principalmente do sertão rural daquele período, enfatizando, na narração, a seca nordestina, a miséria, a fome e a desigualdade.

Levando em conta as particularidades de cada linguagem, o filme de Nelson Pereira dos Santos tem um enredo semelhante ao romance de Graciliano Ramos. Tendo em vista o enredo, procede-se de modo a fazer conexões entre literatura e cinema, trazendo trechos do romance e cenas do filme, atentando ao cunho social de ambas as obras, cujo eixo de análise é a questão do analfabetismo.

Literatura e cinema são fontes inesgotáveis no que se refere ao estudo dos problemas sociais brasileiros, porém, ao fazer um estudo dessas mídias, deve-se ter em mente que cada uma dessas linguagens tem suas peculiaridades: "enquanto na literatura a personagem existe através do extraordinário poder da palavra, o cinema possui outros recursos para a construção dela, que é fixada, sobretudo, por um contexto visual" (BARROS, 2007, p. 9). 
Tais diferenças embasam a riqueza deste estudo ao aproximar literatura e cinema, pois, embora possam tratar de um único enredo - Vidas secas -, pode ser contado e apreciado de modos diversos. Na perspectiva de perceber olhares diferentes ao contar a mesma história, usando de diferentes recursos, os trechos e cenas escolhidos relevam o analfabetismo dos personagens e suas consequências, de certo modo apontadas tanto pelo escritor quanto pelo diretor.

Sobre o analfabetismo é necessário saber que, naquele contexto de 1938, a população brasileira contava com cerca $62 \%$ de analfabetos; porcentagem que abarca, em sua maioria, as pessoas mais pobres, negras e residentes nas zonas rurais.

Desse modo, não é de se estranhar que a família de Fabiano e tantas outras daquele contexto fossem constituídas de gente analfabeta. Nas palavras de Graciliano Ramos, “Ordinariamente a família falava pouco. E depois daquele desastre [a seca] viviam todos calados, raramente soltavam palavras curtas" (RAMOS, 2005, p. 12). Essa é uma das características da família trazida pelo autor do romance. No filme, esse traço é sublinhado logo nas primeiras cenas, em que os personagens caminham por algum tempo em silêncio, silêncio que percebemos por toda a obra. $O$ expectador percebe ainda outras características da família: os sinais de pobreza, seca, cansaço. Em se tratando de adaptação da literatura para o cinema - e pensando nas semelhanças e diferenças dos dois tipos de linguagens -, é importante saber que "um livro é dramaticamente estruturado segundo as bases e a linguagem literárias; o adaptador tem de descontruir a base, preservando o esqueleto do livro, para assim remontá-lo segundo a linguagem cinematográfica" (BARROS, 2007, p. 21).

A seguir veremos um pouco dos personagens, as consequências e prejuízos da condição de analfabeto, começando pelo vaqueiro Fabiano. A partir da narrativa escrita, 
nota-se a animalização: "os pés duros quebravam espinhos e não sentiam a quentura da terra" (RAMOS, 2005, p. 20). Além das características de animalidade, fica clara a falta de habilidade de Fabiano com as palavras.

No filme, por sua vez, para que se fizesse entender e fazer referência ao que está na literatura, o diretor apresenta a cena de adestramento de um cavalo, com o qual Fabiano, exímio adestrador, dá-se muito bem. Tanto o literário quanto o cinematográfico, assim, fazem pensar sobre o comportamento de Fabiano, sua dificuldade em se comunicar com as pessoas. Vale sinalizar que, nas imagens, parece que a animalização de Fabiano é um pouco abrandada (ele não está descalço). Quem leu o livro pode ser influenciado pela leitura e ver nas cenas um Fabiano bruto na lida com os animais. Todavia pode ver também um homem integrado ao animal e à natureza, alguém que faz bem seu trabalho, no caso, ser vaqueiro e adestrar.

Sobre adaptação do texto para a tela, Betton, autor citado por Bomfim (2011, p.23), escreve que é preciso considerar a temporalidade, pois:

[...] é importante reunir o máximo de coisas num mínimo de tempo, exprimir tudo pela ação num tempo limitado, donde a necessidade de estilizar, de suprimir uma grande parte dos elementos do romance que está adaptando para conservar somente o essencial da ação, o que existe de mais significativo nas individualidades. E nesse sentido, a escolha é um ato de criação [...].

Em outro trecho do romance, lemos um pouco mais sobre as características de Fabiano: "sempre havia obedecido. Tinha muque e substância, mas pensava pouco, desejava pouco e obedecia" (RAMOS, 2005, p. 28). 
No filme, além dos gestos visíveis de submissão - cabeça e ombros baixos, chapéu na mão -, ouvimos por várias vezes de Fabiano um "Inhô sim". O "Inhô sim" proferido pelo vaqueiro nos soa como uma obediência de quem não quer discutir, ou de quem sabe que não pode discutir. Nesse sentido, Nelson Pereira dos Santos traz para o filme a característica talvez mais marcante do personagem: "desejava pouco e obedecia". Apesar de serem linguagens diferentes, há sempre indícios que fazem referência à obra fonte, isso acontece porque:

A recriação parte sempre de um dado do livro que chama a atenção do recriador, que ele vai descobrindo aos poucos ou que surge em um repente. Esse dado pode ser o espaço, o clima, a atmosfera, o estilo do escritor, uma imagem, ou mesmo um simples gesto de uma personagem (BARROS, 2007, p. 21).

Vale lembrar de seu Tomás da bolandeira, personagem que o leitor sabe quem é porque ora ou outra é citado por Fabiano ou por sua esposa. Sabemos que é um homem letrado, educado e que possuía uma cama de lastro de couro (sonho de consumo de sinha Vitória). No livro, temos as seguintes informações sobre esse homem admirado pelo casal:

Quando seu Tomás da bolandeira passava, amarelo, sisudo, corcunda, montado num cavalo cego, pé aqui, pé acolá, Fabiano e outros semelhantes descobriam-se. E seu Tomás respondia tocando na beira do chapéu de palha, virava-se para um lado e para o outro, abrindo muito as pernas calçadas em botas pretas com remendos vermelhos.

[...] Seu Tomás da bolandeira falava bem, estragava os olhos em cima de jornais e livros, mas não sabia mandar: pedia. Esquisitice um homem remediado ser cortês. Até o povo censurava aquelas maneiras. Mas todos obedeciam a ele. An! Quem disse que não obedeciam? 
Os outros brancos eram diferentes. O patrão atual, por exemplo, berrava sem precisão (RAMOS, 2005, p. 22-23).

Fabiano, acostumado a ser tratado a gritos e grosserias, achava esquisita a boa educação de seu Tomás da bolandeira, "não sabia mandar: pedia"; e pedindo, obedeciam-no. O narrador talvez quisesse dizer que se aqueles senhores, os brancos ${ }^{\mathrm{i}}-$ como chamados por Fabiano -, tivessem uma "educação" digna, os trabalhadores poderiam ser melhor tratados. Além disso, a ignorância e brutalidade tinham dupla face, isto é, não estavam somente naqueles trabalhadores e retirantes, havia ignorância também nos patrões - quiçá não fosse a mesma, mas fato que a ignorância também estava nos brancos.

Seu Tomás da bolandeira não tem voz no romance, contudo é mencionado muitas vezes por Fabiano e por sinha Vitória, quase sempre com admiração: era o homem das letras e da boa educação, alguém que sabia das coisas, características básicas, por assim dizer, da civilidade, completamente opostas à condição de Fabiano, recoberto por antivalores da barbárie.

Podemos, então, questionar: por que seu Tomás da bolandeira não tem voz, considerando suas tantas qualidades tão importantes para o casal? Talvez porque seu Tomás, naquele momento, seja uma utopia, principalmente para Fabiano que "em horas de maluqueira [...] desejava imitá-lo". (RAMOS, 2005, p. 22). Mas também utopia para sinha Vitória, e quiçá até para o leitor. É o homem que queríamos que estivesse ali naquele cenário. E não está por ser ele estranho ao lugar, no sentido de destoar da brutalidade dos tratos sociais aos quais Fabiano estava acostumado. Seu Tomás da bolandeira não pertence àquele modo de vida dividido entre o mandar e o obedecer. Ao mesmo tempo ele está presente na voz do casal de retirantes. Resta saber se essa 
presença, na verdade, era uma utopia de sociedade projetada por Fabiano e sinha Vitória: como seria a vida se todos, inclusive eles, fossem parecidos com seu Tomás da bolandeira?

No romance e no filme, seu Tomás da bolandeira é trazido pela memória dos personagens. Entretanto, na obra de Santos o nome de Tomás da bolandeira é mencionado apenas em três cenas. Abaixo, a mais longa e importante menção, um diálogo entre o casal:

Sinha Vitória: "que fim levou seu Tumais?"

[momento de silêncio]

Fabiano: "se largou se no mundo como a gente. Será que ele carregou todos os trem junto? A bolandeira garanto que ficou [...]."

Fabiano: [...] tudo de melhor pra seu Tumais, pruquê? Seu Tumás home de valia, seu Tumais falava bem, estragava o zoio em cima do livro [...] home de leitura, disse sempre o que era certo, mesmo quando ia chover [...]."

Sinha Vitória: "[...] um dia vamo ter uma cama de couro igualzinha à de seu Tumais."

Aqui a palavra diálogo pode ser colocada em xeque. Quem assiste à cena fica com a impressão de que eles não estão se ouvindo e, sim, cada um falando pra si. Essa conversa a princípio é compreensiva, mas em seguida Fabiano e sinha Vitória falam ao mesmo tempo e, a certo ponto, as falas não ficam claras, vemos frases cortadas e soltas, umas sobre as outras, de modo que só sabemos que ambos estão falando de seu Tomás da bolandeira. Opção do diretor que pode ter uma riqueza de interpretações, pois "tanto na literatura quanto no cinema, a palavra e imagem são tiradas de seus espaços primeiros, convencionais, para passar a expressar uma subjetividade, e, além disso, tornar-se expressões artísticas" (BARROS, 2007, p. 21). 
Importante frisar algo que na cena transcrita fica claro, qual seja, o modo de falar dos personagens, que no filme é diferente do romance. Enquanto no texto literário permanece a linguagem culta, no texto oral filmado, por sua vez, a fala dos personagens distancia-se do registro culto, as palavras pronunciadas remetem à condição de analfabetismo.

Durante a leitura de Vidas secas, por vezes, traços animalescos compõem Fabiano, o que não impede, conforme vemos no trecho a seguir, que o personagem esteja mais ou menos consciente de sua condição. Preso injustamente, ele alimenta sentimentos de raiva e desgosto. Nesse momento, vem à tona também a consciência da sua situação:

Era bruto, sim senhor, nunca havia aprendido, não sabia explicar-se. Estava preso por isso? Como era? Que mal fazia? Então mete-se um homem na cadeia porque ele não sabia falar direito? Que mal fazia a brutalidade dele? Vivia trabalhando como um escravo. Desentupia o bebedouro, consertava as cercas, curava os animais aproveitara um casco de fazenda sem valor. Tudo em ordem podiam ver. Tinha culpa de ser bruto? Quem teria culpa?

[...] Difícil pensar. Vivia agarrado aos bichos... Nunca vira uma escola. Por isso não conseguia defender-se, botar as coisas nos seus lugares (RAMOS, 2005, p. 35).

O próprio Fabiano mostra saber de si, lendo aquele momento como uma soma de desgraças. O personagem reconhece que não sabe falar direito, que é um bruto, mas se revolta e faz questionamentos: poderia ser preso "por não saber", por ser um bruto? E de quem seria a culpa? Nunca sequer tinha visto uma escola, como poderia se defender? Contudo, ele sabia que era um trabalhador e descreve suas habilidades. Fabiano se diz não saber de muitas coisas, porém o leitor vê que ele sabe de muito, inclusive que "se lhe 
tivessem dado ensino, encontraria meio de entendê-la [a situação]. Impossível, só sabia lidar com bichos" (RAMOS, 2005, p. 35).

No final do desabafo, Fabiano faz referência ao homem que ele tem como exemplo de inteligência e sabedoria: "enfim, contanto... Seu Tomás daria informações. Fossem perguntar a ele. Homem bom, seu Tomás da bolandeira, aprendido. Cada qual como Deus o fez. Ele Fabiano, era aquilo mesmo, um bruto" (RAMOS, 2005, p. 35). Essa última frase demonstra uma espécie de conformismo de quem desconfia ou sabe que as coisas não iriam mudar, pois ele "era aquilo mesmo, um bruto." Todavia, o fato dele nunca sequer ter visto uma escola dá indícios de que poderia haver culpados. Fabiano poderia ter razão, seu Tomás, que era homem bem informado, quiçá soubesse, por exemplo, que o acesso à educação era para poucos e que: "Até fins do século XIX, as oportunidades de acesso à educação no Brasil eram muito reduzidas, restritas, principalmente, aos homens livres proprietários das vilas e cidades, minoria da população" (GALVÃO; DI PIERRO, 2012, p. $57)$.

Estudos mostram que o acesso à educação para os pobres continuou difícil até meados do século XX. Famílias pobres principalmente da zona rural, como as representadas por Fabiano, dificilmente conseguiriam ter acesso à escola. Segundo as estudiosas Galvão e Di Pierro (2012, p. 57-58) “[...] há evidências e documentos históricos que demonstram que a população do campo tinha, sim, interesse pelo estudo, ficando os pobres [...] dele afastados pela falta de professores ou de escolas que pudessem frequentar".

Não é, pois, de se estranhar que Graciliano Ramos tenha escrito um personagem apartado da cultura escolar. No filme, quando trata da prisão de Fabiano, Nelson Pereira dos Santos faz algumas escolhas que mesclam capítulos. Abaixo serão descritas três cenas 
importantes do filme: a primeira trata de Fabiano fazendo contas com o patrão; na segunda, ele é impedido pelo agente da prefeitura; e na terceira é preso pelo soldado amarelo. Veremos que Santos faz esses recortes escolhendo mostrar seguidamente (não exatamente no mesmo dia) os prejuízos e humilhações sofridos por Fabiano até à prisão injusta.

1. Fabiano fazendo contas com o patrão. À certa altura do filme, o personagem entra na casa ao som de um instrumento musical; ele para, ouve um pouco a música e segue pelo corredor da casa grande, encontra o patrão sentado tomando café:

\author{
Fabiano: “Dia!" \\ Patrão: "Sente! Você quer acertar as contas hoje?" \\ Fabiano: "Pois careço de comprar o... [antes de terminar a frase, o patrão \\ interrompe]" \\ Patrão: "Quanto é que the devo mermo?" \\ Fabiano: "Bom... é... quer dizer, é... [interrompido]." \\ Patrão: "Panha a caderneta, tá lá na sala em cima da escrivaninha." \\ Fabiano: "Inhô sim."
}

Fabiano obedece-o sorridente e vai até a sala, pega a caderneta e por um instante para novamente, ouve a música e observa uma menina e um homem (o homem toca um instrumento de corda enquanto a menina olha). Ao perceber que foi visto, desvia o olhar, quase que envergonhado e volta para a cozinha. Em silêncio, o patrão faz as contas e, em seguida, entrega o dinheiro para Fabiano, que conta as cédulas e reclama:

Fabiano: "Me desculpe, mas tem de menos."

O patrão pega o dinheiro, conta de novo e devolve para Fabiano: 
Patrão: "Tá certo!"

Fabiano: "O que a muié disse é mais, aqui tem erro na conta."

Patrão: "A diferença é dos juros, num the emprestei dinheiro todo esse ano? Tem erro não."

Fabiano: "Eu não, mas a muié tem miolo, sabe fazer conta, aqui tem de menos."

Patrão: "Sua paga esta aí, não tem mais nada pra receber."

Fabiano: "Isto não tá certo! Sô nego não [joga o dinheiro em cima da mesa]"

Patrão: "Nego num tem nenhum aqui! Leva o seu dinheiro! [joga o dinheiro para o lado de Fabiano]. "E se não quiser vai procurar emprego em outro lugar! Cabra insolente não trabalha comigo."

Fabiano: [abaixa a voz] "Bem... bem... não é preciso barulho, foi palavra atoa... me desculpe, foi culpa da muié, patrão, eu não sei ler... a véia me disse é tanto, eu acreditei nela."

Patrão: "Está bem, Fabiano, vai trabaiá."

Fabiano: "Mas noutra eu não caio não, sinhô, me desculpe"

Termina a conversa e Fabiano sai de cabeça baixa e chapéu na mão. A menina, provavelmente filha do patrão, e o homem - possivelmente seu professor - não aparecem no texto literário. Quem leu o livro pode se perguntar o que eles estão fazendo ali. A cena de uma aula na casa do patrão de Fabiano indica que Santos procurou sublinhar que as aulas não eram para todos. No romance está dito implicitamente a condição de analfabetismo de Fabiano e sua família. Como afirma Robert Stam (2006, p. 27), “[...] qualquer romance pode gerar um número infinito de leituras para adaptação, que serão inevitavelmente parciais, pessoais, conjunturais, com interesses específicos".

2. Impedido pelo agente da prefeitura. Tira um saco das costas e, na calçada, Fabiano oferece à freguesa carne de porco; ao lado, na esquina, um agente da prefeitura conversa com o soldado amarelo: 
Agente da prefeitura: "Ei, Moço! Ei, já tem a guia de imposto? [caminha em direção a Fabiano]. Pra vender tem que tem pagar imposto à prefeitura."

Fabiano: "Num sei nada de imposto, não" [já amarrando o saco].

Agente da prefeitura: “O porco é seu? É pra vender?"

Fabiano: [responde sim com a cabeça].

Agente da prefeitura: "Então tem que pagar imposto."

Fabiano: [Já saindo com o saco nas costas] "Mas isso não é porco, não, sinhô, isso é pedaço de porco."

Agente da prefeitura: "Num interessa, se é pra vender tem que pagar imposto, seu cabra safado, tá me desacatando?"

Fabiano: "Me desculpe, seu moço. Pensei que pudia dispor dos meus troços, não sabia desse tal de imposto."

Agente da prefeitura: "Pois fique sabendo!"

Fabiano: "Não sabia que a prefeitura tinha parte do meu cevado, mas como o sinhô disse, tá acabado... [vai saindo] Levo a carne pra casa e dou pra família, posso comer a carne. Posso ou não posso?"

Agente da prefeitura: "Tá conversando! Vai embora!"

Assiste-se a Fabiano sair olhando para trás um tanto amedrontado, ele parece ter noção que novamente foi logrado.

3. Preso pelo soldado amarelo. Fabiano sai de dentro do bar, onde estava jogando, e é seguido pelo soldado amarelo. O soldado puxa-o pelas costas e empurra-o. Fabiano recolhe os pertences que caíram no chão e vê que já são muitas pessoas em volta, então ele se volta para o soldado:

Fabiano: "Vosmicê não tem o direito de provocar os que tão queto."

Soldado amarelo: "Desafasta, seu cabra sem vergonha! Então é jeito de tratar seus parceiros de jogo?! Dar as costas sem dizer até logo?!"

Fabiano: "Lorota! Eu tenho culpa de vosmicê esbagaçar seus possuído no jogo? 
O soldado, em silêncio, caminha em volta de Fabiano com um olhar ameaçador, em seguida pisoteia o pé dele, que reage:

Fabiano: "Isso não se faz, moço, eu estou queto! Veja que mole e quente é pé da gente! [empurra o soldado xingando-o] Filho de uma égua!"

O soldado começa a apitar com força, vêm outros soldados e levam Fabiano para a delegacia. Lá o soldado amarelo afirma que Fabiano desacatou a farda e o ofendeu na frente de todos e que por isso merecia uma lição para não afrontar as autoridades. Fabiano é surrado e jogado dentro de uma cela, onde chora e geme (de raiva, de revolta, de dor...), enquanto a festa acontece na rua.

Parte das humilhações e prejuízos sofridos por Fabiano acontece não só pela pobreza, mas também pela condição de analfabeto. "Não saber ler e escrever é, como outras marcas distintivas da pobreza, um símbolo da condição de subalternidade" (MELLO; GOMES apud GALVÃO; DI PIERRO, 2012, p. 18).

As cenas transcritas partem do romance, porém existem diferenças importantes. Santos fez recortes e acréscimos, mudanças de ordem, escolhas que são bastante necessárias para uma adaptação para o cinema. Para Bomfim, no cinema,

é permitida a construção de um através da combinação de partes na realidade pertencentes a totalidades distintas; podemos combinar o plano de um rosto de uma pessoa com um plano das mãos de outra, e assim sucessivamente para todo o corpo, compondo desse modo uma unidade original na tela $(2011$, p. 16$)$. 
Até aqui, percebe-se os prejuízos e danos causados pela falta da escola na vida dos personagens. O excerto varia um tanto mais a questão: o analfabeto nem sempre é logrado por não saber.

Sinha Vitória mandou os meninos para o barreiro, sentou-se na cozinha, concentrouse, distribuiu no chão sementes de várias espécies, realizou somas e diminuições. No dia seguinte Fabiano voltou à cidade, mas ao fechar o negócio notou que as operações de sinha Vitória, como de costume, diferiam das do patrão. Reclamou e obteve a explicação habitual: a diferença era proveniente de juros.

Não se conformou: devia haver engano. Ele era bruto, sim senhor, via se perfeitamente que era bruto, mas a mulher tinha miolo. Com certeza havia erro no papel do branco. Não se descobriu o erro, e Fabiano perdeu os estribos (RAMOS, 2005, p. 94).

Sinha Vitória fazia contas, característica verossímil, dado que indivíduos na mesma condição de analfabetismo têm conhecimentos variados. Graciliano Ramos escreve uma personagem analfabeta que desenvolveu a habilidade de fazer somas e diminuições, destreza normalmente aprendida na escola. Nem no romance, nem no filme é possível ter certeza de como sinha Vitória adquiriu tal competência, no entanto, é possível intuir que ela tenha visto alguém fazê-las ou tenha desenvolvido seus métodos de contagem na própria lida diária - veja que ela usa sementes de várias espécies, ou seja, utensílios do seu cotidiano. É que pela oralidade se ensina e aprende uma porção de técnicas e narrativas, da agricultura à vida de Jesus Cristo. Pode-se intuir, ainda, que fazer contas resulte de um mecanismo de defesa para que ela e os seus não fossem roubados.

Ainda assim, a conta que vale é a do papel do "branco". Sinha Vitória e tantos outros com algum conhecimento matemático não têm o poder do lápis, do papel e da escola para questionarem os cálculos e a lei. Embora afirmando que a conta da esposa 
estava certa, Fabiano concorda em receber menos, abaixa a cabeça, pede desculpas e vai embora. Nesse caso, saber ou não calcular pouco importa, pois é o estigma de ser analfabeto que vai decidir se um argumento tem ou não autoridade, independentemente de estar correto. O patrão de Fabiano sabia que não podia ser questionado por um analfabeto subalterno, a ponto de pagar a Fabiano o tanto que quisesse.

$\mathrm{Na}$ adaptação de Nelson Pereira dos Santos, as duas situações - sinha Vitória fazendo as contas e Fabiano com o patrão - aparecem conforme o romance, mas com algumas alterações de ordem. Outro diferencial é que na obra de Santos sinha Vitória, logo após fazer as contas, dá opinião e faz planos em relação ao dinheiro que Fabiano supostamente receberia. A opção do diretor sinaliza a participação da esposa de Fabiano no planejamento financeiro da família, é ela quem decide o que fazer com o que sobrar do dinheiro.

Temos, então, no filme, uma sequência de cenas e diálogos sobre as contas. Depois de uma fala de Fabiano - "O patrão disse que é cem mil réis por cabeça" -, Sinha Vitória manda as crianças saírem e começa a fazer as contas. 
Figura 1 - Cena do filme Vidas secas (1963) - Sinha Vitória contando

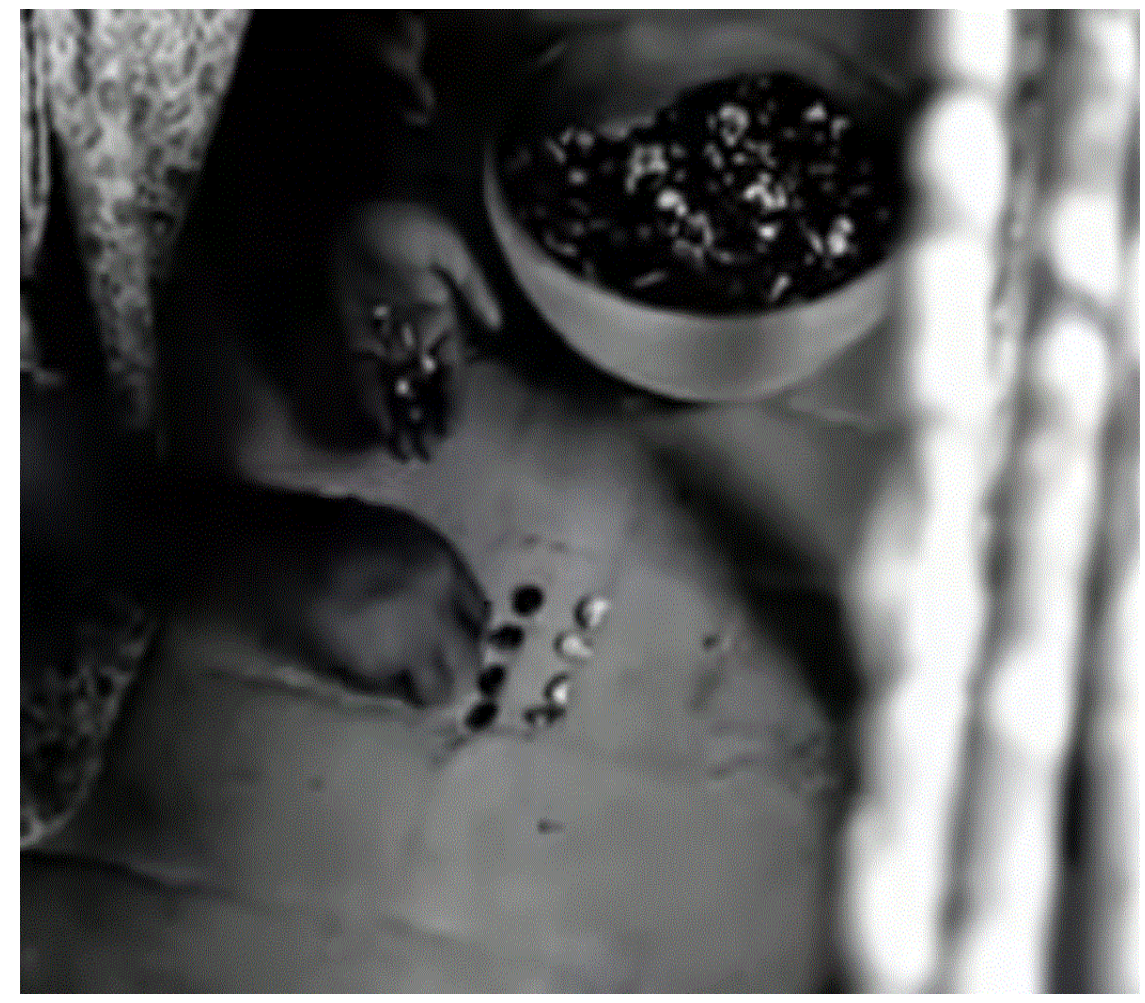

Fonte: Arquivo pessoal da pesquisadora

Logo em seguida, começa um diálogo:

Sinha Vitória: “É... o dinheiro dá pra acertar as contas com o patrão e com a sobra a gente compra o couro pra fazer uma cama igualzinho a de seu Tumáis... Se precisar a gente gasta de menos."

Fabiano: "É... a gente gasta de menos."

Sinha Vitória: "Vamo dormir em cama de couro, vamo ser gente!

Ser gente para sinha Vitória estava relacionado ao poder de compra da família, capaz de redundar em melhores condições de vida - que tivessem ao menos uma cama digna para dormir, pois viver como viviam, dormir como dormiam, eram condições de bicho, como ela mesma dizia. Heloisa Starling (2008, p. 138) escreve que Graciliano Ramos 
enunciou a importância de projetar, no imaginário político republicano gerado por essa matriz literária e ao lado de uma República repleta de ruínas precoces, uma poética da escassez, [...] a consciência sobre a existência política dos brasileiros párias - uma gente anônima e insignificante, simples e obscura que, como já havia sido apontado por Euclides da Cunha, movimentava-se, precariamente, no vazio da nação, à mercê de uma República que não os reivindica nunca.

E os filhos de Fabiano e de sinha Vitória? Esses que nem sequer sabemos o nome, mas cuja presença é marcante, trazem indícios de um futuro que é mesmo sem nome, cheio de dúvidas. Lendo o romance ou assistindo ao filme pode-se perguntar: que será dessas crianças?

Indispensável os meninos entrarem no bom caminho, saberem cortar mandacaru para o gado, consertar cercas, amansar brabos. Precisavam ser duros, virar tatus. [...] Um dia... Sim, quando as secas desaparecessem e tudo andasse direito... Seria que as secas iriam desaparecer e tudo andar certo? Não sabia. Seu Tomás da bolandeira é que devia ter lido isso. Livres daquele perigo, os meninos poderiam falar, perguntar, encher-se de caprichos. Agora tinham obrigação de comporta-se como gente da laia deles (RAMOS, 2005, p. 24-25).

O pai tem consciência do estado de miséria, sabia (ou achava que sabia) o que os filhos deveriam aprender, pelo menos naquele momento. Os meninos tinham que aprender as obrigações de "gente da laia deles": saber as obrigações significa aprender, como ele, o pai, a obedecer, fazer os serviços da roça e também a suportar as durezas de uma vida subsistente. Todavia, Fabiano sonha: quando fossem livres os meninos poderiam encher-se de caprichos e até... Quem diria? Com a liberdade de tempos vindouros as crianças poderiam se dar ao luxo de fazer perguntas. Talvez por isso Fabiano 
fosse tão calado, ele tinha conhecimento a que "laia" ele pertencia. Essa "laia", como é possível ler e assistir em Vidas secas, não tem muita voz.

Citando Garbuglio (et al.) e Miranda, a estudiosa Starling (2008, p. 139) aponta para a espantosa improdutividade de um tempo que se arrasta, um tempo que passa em vão, oscila, num vai e vem infinito e, no seu rastro, deixa tudo exatamente como estava.

O desfecho do enredo Vidas secas pode ser visto com esperança ou não, os momentos últimos são sintomáticos: por um lado, vê-se a família de Fabiano novamente fugindo da miséria, e isso não nos dá esperança. Conforme escreve Starling (2008, p. 136), trata-se de "uma gente condenada ao absurdo de viver 'expatriada dentro da própria pátria', como definiu o próprio Euclides, consumindo uma vida onde a esperança é provisória e onde não cabe sequer sentir saudades do sonho de possuir uma terra e habitá-la em comum". Por outro lado, naquela viagem, sem destino certo, tem-se a impressão que Fabiano e sinha Vitória estavam mais falantes e, com esperança faziam planos para eles e as crianças:

Fabiano estava contente e acreditava nessa terra, por que não sabia como ela era nem onde era. Repetia docilmente as palavras de sinha Vitória [...] E andavam para o sul metido naquele sonho. Uma cidade grande, cheia de pessoas fortes. Os meninos em escolas, aprendendo coisas difíceis e necessárias (RAMOS, 2005, p. 127-128).

Abaixo, a imagem da família de Fabiano, novamente fugindo da miséria, também o cenário em que conversam: queixavam-se e faziam planos para o futuro. 
Figura 2 - Cena final do filme Vidas secas (1963)

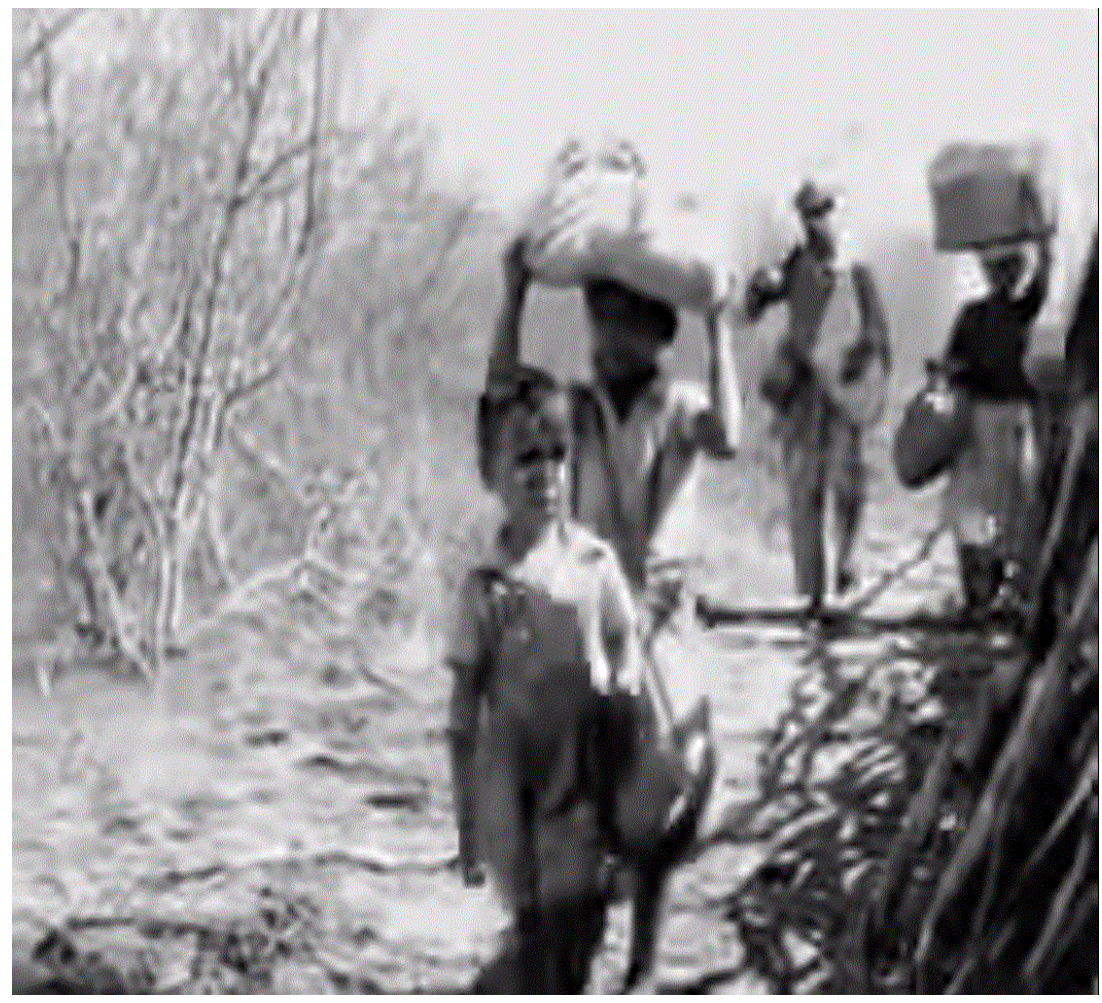

Fonte: Arquivo pessoal da pesquisadora

Ler um romance e assistir ao filme são experiências diferentes entre si, por isso cada obra deve ter uma atenção de acordo com cada peculiaridade. Portanto, é válido lembrar que, para a teoria da recepção, um texto é um evento cujas indeterminações são completadas e se tornam verdadeiras quando lido (ou assistido). Não é mero "retrato" de uma realidade pré-existente. Tanto o romance como o filme são expressões comunicativas, situadas socialmente e moldadas historicamente (STAM, 2006, p. 24-25). Nesse sentido, Vidas secas, tanto o romance (1938) como o filme (1963), vão se completando com os olhares. As obras aqui analisadas têm uma rica fortuna crítica, cujos olhares são de variadas perspectivas. Este artigo, por sua vez, lança um olhar sobre o analfabetismo. 


\section{Referências}

BARROS, Antônio Claudio da Silva. A Literatura na tela grande: obras de Rubem Fonseca adaptadas para o cinema. Dissertação (Mestrado em Letras), Brasília, Universidade de Brasília, 2007.

BOMFIM, Júlio César. Vidas secas, do livro ao filme estudo sobre o processo de adaptação. Dissertação (Mestrado em Letras), São Paulo, Universidade de São Paulo, 2011.

CANDIDO, Antônio. Literatura e sociedade. Rio de Janeiro: Ouro sobre Azul, 2006.

GALVÃO, Ana Maria de Oliveira; DI PIERRO, Maria Clara. Preconceito contra o analfabeto. 2 ed. São Paulo: Cortez, 2012.

RAMOS, Graciliano. Vidas secas. 97 ed. Rio de Janeiro: Record, 2005.

SANGION, Juliana. Realismo e realidade no cinema brasileiro - de Rio, 40 Graus a Cidade de Deus. Caligrama (ECA/USP), v. 1, n. 3, 2005, p. 2-9.

STAM, Robert. Teoria e prática da adaptação: da fidelidade à intertextualidade. Ilha do Desterro, Florianópolis, n. 51, 2006, p. 19-53.

STARLING, Heloisa Maria Murgel. A república e o sertão: imaginação literária e republicanismo no Brasil. Revista Crítica de Ciências Sociais, 2008, p. 133-147.

SANTOS, Nelson Pereira dos. Vidas secas. Rio de Janeiro: Sino Filmes, 1963, 103 min. [filme].

\footnotetext{
'Entende-se que "brancos" sejam os patrões e provavelmente as pessoas mais remediadas. Em se tratando da cor da pele, Fabiano também era branco: "Vermelho, queimado, tinha os olhos azuis, a barba e os cabelos ruivos; mas como vivia em terra alheia, cuidava de animais alheios, descobria-se, encolhia-se na presença dos brancos e julgava-se cabra." (RAMOS, 2005, p. 18). Sendo assim, "branco" ganha outro sentido no romance, passa a ser uma categoria social mais que racial.
}

Recebido em 14 de março de 2018.

Aceito em 25 de abril de 2018. 